\title{
The Family Decision Making Patterns of Children with Special Needs: a Sociology Study of the Family
}

\author{
Fatimah Azis ${ }^{1 *}$, Sam'un Mukramin ${ }^{2}$ \\ ${ }^{1,2}$ Pendidikan Sosiologi, Fakultas Keguruan dan Ilmu Pendidikan, \\ Universitas Muhammadiyah Makassar, Makassar, Indonesia \\ *e-mail: fatimah.azis@unismuh.ac.id
}

\begin{abstract}
This study aims to explain information about the patterns of family decision making for parents who have children with special needs in the city of Makassar. This type of research is descriptive qualitative. The results of the study show that parents are key figures who play a very important role in providing role models, guidance, and affection in the process of child development. The role of parents in the acceptance of children with special needs is very important. Parents are the best guides and helpers for the independence of children with special needs. The mother as one of the parents of children with special needs has an important role in understanding the needs and development of their children. This is related to the mother's acceptance of children with disabilities, which is shown in the attitude to face children. If parents lack understanding of children with special needs, it can result in a lack of attention and consider the child to be unlucky in the family. Parents are the determinants of a child's life before and after birth. Therefore, it is the responsibility of parents to fully accept the existence of their children and treat them equally in all aspects of life with children in general without any discriminatory attitude and to provide the widest possible opportunity for education.
\end{abstract}

Keywords: Decision making patterns, family role, children with special needs

\begin{abstract}
Abstrak
Penelitian ini mencari informasi tentang bagaimana pola asuh orangtua terhadap anak-anak berkebutuhan khusus di Kota Makassar. Penelitian ini menggunakan metode kualitatif deskriptif. Hasil penelitian ini menunjukkan bahwa orangtua memiliki peran yang sangat penting karena sebagai teladan, pendidik dan pemberi kasih sayang terhadap anak. Orangtua juga memiliki peran sebagai penerima segala kekurangan yang dimiliki oleh anaknya. Mereka adalah teladan baik untuk membantu anaknya hidup mandiri. Khususnya ibu yang memiliki peran yang sangat penting dalam memahami kebutuhan perkembangan anak. Ini sangat berkaitan erat dengan kegiatan ibu dalam mendidik anak berkebutuhan khusus karena memiliki sifat yang ramah terhadap anak. Jika orangtua kurang memahami kebutuhan anak disabilitas, maka anak tersebut kekurangan perhatian di dalam keluarga. Orangtua adalah penentu kehidupan anak sebelum mereka hidup mandiri. Oleh karena itu, menjadi tanggung jawab orang tua untuk menerima sepenuhnya keberadaan anaknya dan memperlakukan mereka secara setara dalam segala aspek kehidupan dengan anak pada umumnya tanpa ada sikap diskriminatif serta memberikan kesempatan pendidikan seluas-luasnya.
\end{abstract}

Kata Kunci: Pola pengambilan keputusan, peran keluarga, anak berkebutuhan khusus 


\section{Introduction}

Family is the smallest unit in the society which according to its type is divided into two, namely nuclear family extended family (Edwards, McCarthy, \& Gillies, 2012). In a psychological sense, a family is a group of people who live together in a joint residence and each member feels an inner connection so that there is mutual influence, mutual care, and mutual surrender. In a pedagogical sense, the family is "one" communion of life which is formed by affection between two types of humans which is confirmed by marriage intended to perfect each other. To complement and enhance each other, there is the realization of the role and function of parents (Moran-Ellis, 2010). If we narrow down the definition, the family can be defined as a group of people who live under one roof where they are dependent on each other. From this opinion, it can be concluded that what is meant by a family is those who live in the same house or one roof, be it blood ties or non-blood ties. So in this case, the definition of family is limited by where it lives (Roja, 2020; Syahrul, 2017).

This can be concluded that family is the smallest unit of society consisting of two or more, their bond of marriage or consanguinity, live in a household under the care of a householder, interaction among family members, and each family member has their respective roles, maintaining a custom and culture of its own. In a sociological sense, in general, the family can be defined as a group of people who are united by ties of marriage, blood, or adoption, constituting their household structure, interacting and communicating with each other which creates social roles for husband and wife, father and mother, sons and daughters, brothers and sisters, and in the maintenance of a common culture. So the family is a social unit bound by blood relations and each member has a different role according to its function (Connell, 2014).

Duvall and Logan said that the family is a group of people with ties of marriage, birth, and adoption that aim to create, maintain a culture, and enhance the physical, mental, emotional, and social development of each family member (Kimbrough et al., 2019). Bailon and Maglaya said that the family is two or more individuals who live in one household because of blood relations, marriage, or adoption (Bailon, 2008). They interact with each other, have their respective roles, and create and maintain a culture. Family is the first level and intermediary in cultural transmission.

The family is a small community unit which is also a small group of society. The definition of family according to the Indonesian Ministry of Health is the smallest unit of society consisting of the head of the family and several people who gather and live in a place under one roof in a state of interdependence. Definition of the family by Salvicion and Celis is two or more individuals who are joined by blood, marital relations, or adoption and they live in a household, interact with each other, and in their respective roles and create and maintain a culture (Irianti, 2020).

The general definition is the smallest social unit or social group consisting of a father, mother, one or more children, or without children who are tied to a marriage in which there are affection and responsibility and in which children are cared for. To be someone who has a social sense. The family is the basic social institution from which all other social institutions or institutions develop. In society any in the world, the family is a universal human need and is the most important centre of activity in individual life (Suyanto \& Narwoko, 2007).

Related to that, Friedman divided into nuclear family, orientation family, extended family (Friedman, Hamilton, Samuelson, Lundgren, \& Pott, 2013). The nuclear family consists of husband and wife and their children, biological both and adopted children. Family orientation (original family) is a family unit in which a person is born. The 
extended family is the nuclear family plus other family members who are still related by blood, such as grandparents, uncles, and aunts (Suprajitno, 2019). A family essentially has a function as a generation continuous, which means that in fact, every family has a desire to have children in maintaining the continuity of the family's descendants.

The function of socialization is a learning process, act, behaviour, and wishes regarding the rules, norms, and values in the group. In other words, this socialization is a process of introducing and instilling new values and norms in society. Family is a socialization function for family members, especially children because the first time a child is born is in the family which is the first and foremost institution. The first time the child gets to know the rules, norms, and values are in the family. How the child knows his role and status in society, the family teaches him. This is taught by families to children so that children can play their role and status properly in society.

The function of affection provides love and affection, in the sense that in the family there is a sense of affection and love among family members. So that there is a strong inner bond in the family. Because basically in human life, not only physical needs must be met but spiritual needs are also very important because they will affect children's behaviour. The family also an institution that protects family members, so that it will create a sense of security and peace.

A family has a function as an economic tool to earn a living and manage the family. In the family, there are also economic activities, such as production and consumption activities. A family has a function to lay and instil the foundations of religion for children and family members. The family function has a function to educate children before entering school formally. This function is also to educate children from the beginning to the growth of children to form their personalities. Children are born without social provisions so that the child can participate, they must be socialized by their parents about the values that exist in society. So, in other words, children must learn the norms of what is good and inappropriate in society. Based on this, the children must obtain standards regarding what values are allowed, and what is not, what is good, what is beautiful, what is proper, etc. They must be able to communicate with other community members by mastering the means.

In the family, children get the main aspects of their personality, their behaviour, their behaviour, their attitudes, and their emotional reactions. That's why the family is an intermediary between society at large and individuals. It should be noted that a person's personality is put at a very young time and one that has a huge influence on one's personality is the family, especially the mother. The role of parents is very important because intervention cannot be carried out if the people around them are not ready to accept the existence of the child. Sincere acceptance coupled with love plays an important role in one's future progress. Parental love will lead children to discover the hidden potential behind their shortcomings. "Love and sincere acceptance from parents is an extraordinary therapy for children with special needs.

Children with special needs need parental attention because of the various obstacles they experience, both physical and environmental (Creswell, 2013). Parents have a big role in making choices. Therefore, this study aims to explain information about the patterns of family decision making for parents who have children with special needs in the city of Makassar.

\section{Research Method}

This research is descriptive qualitative. This type used to comprehensively understand data information related to the object of research by Creswell says it is an 
analysis of methods to explore and understand the meaning of individuals or groups of people who are considered to come from social or humanitarian problems with the study approach (Creswell, 2013). Creswell mentions the case study research method as one of the qualitative research strategies (Moleong, 2018). The classification of this research into the type of case study research refers to community studies that aim to deepen knowledge about a particular phenomenon. This research carried out in-depth and specifically limited to children with special needs, focus on real events and not engineering, and occur in families. Data collection carried out from various sources including children with special needs. Parents, school components, special education teachers, communities in the school environment, and reliable sources to support the completeness of this research data. The data analysis when the researcher collects data. Focusing of the research carried out in the city of Makassar, namely, the role of parents in children with special needs can be seen when making social contacts in matters of social interaction, and it is difficult to interact with both friends and parents. Meanwhile, the data collection used observation, in-depth interviews, and documentation, from primary and secondary school (Sugiyono, 2005).

\section{Results}

The application of structural-functional theory in the context of the family by Emile Durkheim (1961), is seen from the structure and established rules. That a family is a universal unit that has regulations, such as regulations for children to learn to be independent. Without the rules or functions carried out by the family unit, the family unit has no meaning that can produce happiness. Even in the absence of regulations, a future generation will grow or form who do not have better creations and will have problems emotionally and live without direction.

\section{The Role of Functional Structural Theory in the Family}

The application of functional structural theory in the context of the family can be seen from the structure and established rules. That a family is a universal unit that has regulations, such as regulations for children to learn to be independent. Without the rules or functions carried out by the family unit, the family unit has no meaning that can produce happiness. Even in the absence of regulations, a future generation will grow or form who do not have better creations and will have problems emotionally and live without direction. Chapman added that the family in Western culture over the last thirty years has undergone extraordinary changes and has lost its way. This happens because of the western culture which emphasizes materialism with a focus on possessing objects such as houses and cars, and more seeking personal happiness above all else, while sounds from the east point to unity and harmony with nature. Thus the modern family stands at a crossroads, confused and unsure of which path to take. According to supporters of this theory, harmony in the division, and implementation of roles, allocation of solidarity, and commitment to rights, obligations, and shared values are the main conditions for the functioning of the family.

On the other hand, families that cannot function properly, due to the absence of these conditions, will be the main producers of problem children. To carry out its functions optimally, namely increasing the degree of "functionality" of the family must have a certain structure. The structure is the 'role arrangement in which a social system is structured. The term "social system" is very crucial for functionalists; it is a broader construct under the structure so that role regulation occurs (Bell \& Vogel, 1968). Mcintyre observed that a system such as the family has a kind of role. "First, a social 
system such as the family has a differentiated" or special role. Second, roles are organized around the shared norms and values that define the actors. Rights and obligations to one another, and also of the people. The third system is keeping the limit "for the internal actors more strongly bound to one another than external actors. Finally, and most importantly, a social system has a tendency toward homeostasis, or balance, which means it has a mechanism built-in that goes to maintain the condition which is steady both static and stability moves within a certain period (Vörösmarty et al., 2010).

The instrumental role is associated with the role of earning a living for the survival of all family members. While the expressive emotional role is the role of the giver of love, tenderness, and affection. This role aims to integrate or create a harmonious atmosphere in the family and reduce the pressures that occur due to social interactions between members of the family or between individuals outside the family. It is hoped that this role differentiation can lead to an equilibrium tendency.

\section{The Role of Families in Education for Children with Special Needs}

Families play an important role in the development of a child because childhood is a period that is so important to lay the foundations of personality that will give colour when a child becomes an adult. Therefore, the quality of the patterns of childhood development is very important. The family has a major role in caring for children, in all norms and ethics that apply in society, and culture can be passed on from parents to children from generations that are adapted to the development of society (Hulukati \& Hulukati, 2015).

The family has an important role in improving the quality of human resources. Moral education in the family needs to be instilled from an early age in each individual. However, apart from the level of education, individual morale is also a measure of the success or failure of development. The development of science and technology plays an important role and greatly influences the development of attitudes and intellectuality of the young generation as the nation's successor. The family again plays an important role in improving the quality of human resources.

Various aspects of a nation's development cannot be separated from various aspects that support each other, one of which is human resources. It can be seen from the broad outlines of the state policy that the population is a potential and productive human resource for national development. This also cannot be separated from the role and support of the family as shaping individual character and morale so that it becomes a quality human resource. The successful development of a nation requires good quality human resources. To obtain good quality human resources, of course, requires various ways. One of them is through education. Education is both formal and informal. One of the moral education in the family.

Despite having a high level of education, but low in terms of morality, the individual will not be meaningful in the eyes of anyone. Moral education starts with a family that instils a noble character in every interaction. Quality human resources can be seen by their families. It is not only material families that can improve their individual quality through additional learning materials outside of school. However, even a simple family in the village can guarantee the quality of its human resources. The quality of the resources and the nobility of character are the result of being wrought by parents.

The existence of children with special needs in regular schools is a good opportunity for them to socialize, play, and cooperate with children in general. The relationship between them is certainly not as smooth as we imagine. This relationship must be built and based on awareness so that it is possible to become a harmonious relationship. A harmonious relationship is the beginning of the emergence of a sense of 
empathy and trust. Finally, empathy and trust encourage communication between them. Empathy implies that someone tries to understand the condition of another person as that person understands and conveys that understanding to him (Syahrul, 2019). Empathy means stepping into a person and seeing things from that person's side as if he were that person. A person is said to have empathy if he can appreciate the state of feelings of others and can see the outside according to the person's reference pattern, and communicate appreciation that he understands the feelings, behaviour, and experiences of that person personally.

In society, children with special needs are often treated inappropriately and especially normal children in public schools, relatively accepting the presence of children with disabilities in their environment, as a result, children with special needs feel inferior and cannot make contact with their environment, so that their potential cannot develop optimally. Parents and society also think that children with special needs are a social burden in society, so they don't need to get educational services. Mudjito admits that the biggest obstacle in the development of education for children with special needs is the social conditions and society of Indonesia (Maftuhatin, 2014). Often parents are embarrassed to have disabled children, so they hide their children. As a result, children do not get an education like other children. Even though the rights of children with disabilities are the same as other normal children. Protected by UndangUndang Sistem Pendidikan Nasional No. 20 of 2003, which states that every citizen has the same opportunity to obtain an education. Therefore, the government asks parents' awareness to give them access.

\section{Conclusion}

Parents who accept the existence of children with special needs will place their children in an important position in the family and develop a warm emotional relationship with the child. Porter revealed that the aspects of parental acceptance of children are as follows: respecting children as individuals with all feelings acknowledging children's rights and fulfilling the need to express feelings, assessing their children is unique so that parents can maintain their uniqueness indefinitely so that they can become healthy individuals, recognizing children's needs to differentiate and separate themselves from parents and to love independent individuals, and loving children unconditionally. Based on the description above it can be concluded that the aspects of acceptance/role of parents in constructing children with special needs include respecting children as individuals with all their feelings, recognizing children's rights, and fulfilling the need to express feelings, loving children unconditionally, showing anxiety. Which is minimal in the presence of the child, accepting the child's limitations, no rejection is shown to the child, and there are communication and warmth between parents and children.

\section{References}

Bailon, S. G. (2008). Maglaya. Family Nursing Book. Jakarta: EGC.

Bell, N. W., \& Vogel, E. F. (1968). A modern introduction to the family.

Connell, R. (2014). The sociology of gender in Southern perspective. Current Sociology, 62(4), 550-567. https://doi.org/10.1177/0011392114524510

Creswell, J. W. (2013). Qualitative Inquiryand Researc Design. New Delhi: SAGE Publication.

Edwards, R., McCarthy, J. R., \& Gillies, V. (2012). The politics of concepts: family and its (putative) replacements. The British Journal of Sociology, 63(4), 730-746. 
https://doi.org/https://doi.org/10.1111/j.1468-4446.2012.01434.x

Friedman, M., Hamilton, C., Samuelson, C. G., Lundgren, M. E., \& Pott, T. (2013). Diagnostic Value of the Friedman Tongue Position and Mallampati Classification for Obstructive Sleep Apnea: A Meta-analysis. Otolaryngology-Head and Neck Surgery, 148(4), 540-547. https://doi.org/10.1177/0194599812473413

Hulukati, W., \& Hulukati, W. (2015). Peran lingkungan keluarga terhadap perkembangan anak. Jurnal Musawa IAIN Palu, 7(2), 265-282.

Irianti, R. D. (2020). Kekerasan dalam Rumah Tangga antara Mempertahankan Keutuhan Keluarga dan Sanki Pidana Menurut Undang-Undang Nomor 23 Tahun 2004 Tentang Penghapusan Kekerasan dalam Rumah Tangga. Pamulang Law Review, 3(2), 139-148.

Kimbrough, S., Krabbe, S., Baldauf, R., Barzyk, T., Brown, M., Brown, S., ... Shields, A. (2019). The Kansas City Transportation and Local-Scale Air Quality Study (KC-TRAQS): Integration of Low-Cost Sensors and Reference Grade Monitoring in a Complex Metropolitan Area. Part 1: Overview of the Project. Chemosensors, 7(2), 26. https://doi.org/10.3390/chemosensors7020026

Maftuhatin, L. (2014). Evaluasi Pembelajaran Anak Berkebutuhan Khusus (SBK) di Kelas Inklusif di SD Plus Darul 'Ulum Jombang. Religi: Jurnal Studi Islam, 5(2), 201-227.

Moleong, L. J. (2018). Metodologi penelitian kualitatif. Bandung: PT Remaja Rosda Karya.

Moran-Ellis, J. (2010). Reflections on the Sociology of Childhood in the UK. Current Sociology, 58(2), 186-205. https://doi.org/10.1177/0011392109354241

Roja, M. L. (2020). Kebijakan Pendidikan Anak Terlantar di Panti Asuhan St. Louis De Monfort Kota Kupang. Sociological Education, 1(1), 1-10. https://doi.org/10.12345/socioedu.v1i1.238

Sugiyono. (2005). Memahami penelitian kualitatif. Bandung: Alfabeta.

Suprajitno, S. (2019). Asuhan keperawatan keluarga: aplikasi dalam praktik (67). Ilmu Keperawatan.

Suyanto, J. D. N.-B., \& Narwoko, J. D. (2007). Sosiologi teks pengantar \& terapan. Jakarta: Kencana, Cet, 3.

Syahrul, S. (2017). Dilema Feminis Sebagai Reaksi Maskulin dalam Tradisi Pernikahan Bugis Makassar. AL-MAIYYAH: Media Transformasi Gender Dalam Paradigma Sosial Keagamaan, 10(2), 313-334.

Syahrul, S. (2019). Internalisasi Pendidikan Multikultural dan Inklusif pada Anak Pengungsi Internasional di Kota Makassar. JPK (Jurnal Pancasila dan Kewarganegaraan), 4(3), 25-34. https://doi.org/10.24269/jpk.v4.n3.2019.pp25-34

Vörösmarty, C. J., McIntyre, P. B., Gessner, M. O., Dudgeon, D., Prusevich, A., Green, P., ... Davies, P. M. (2010). Global threats to human water security and river biodiversity. Nature, 467(7315), 555-561. https://doi.org/10.1038/nature09440

Zahrawati B, F. (2018). Membebaskan Anak Tunadaksa dalam Mewujudkan Masyarakat Multikultural Demokratis. Al-Maiyyah: Media Transformasi Gender dalam Paradigma Sosial Keagamaan, 11(1), 171-188. 